\title{
Epidemiology and Clinical Features of Maternal Sepsis \A Retrospective Study of Whole Pregnancy Period
}

\section{Xuan Zhong}

Guangdong Women and Children Hospital

\section{Rongfeng Lin}

Guangzhou University of Chinese Medicine

Wenni Zhang

Guangdong Women and Children Hospital

Yiping Luo

Guangdong Women and Children Hospital

Ding Wang ( $\sim$ largestone_1984@163.com )

The Third Affiliated Hospital of Guangzhou Medical University

\section{Research Article}

Keywords: epidemiology, maternal sepsis, bad outcome, organism isolation, Southeast China

Posted Date: June 16th, 2021

DOI: https://doi.org/10.21203/rs.3.rs-604723/v1

License: @) (1) This work is licensed under a Creative Commons Attribution 4.0 International License. Read Full License 


\section{Abstract}

Background: Maternal sepsis results in poor outcomes such as fetal or maternal death. The incidence and mortality rates of maternal sepsis are variable in different places because of differences in economic development, race, medical conditions, etc. Identifying the clinical features and determining the possible mechanisms for avoiding morbidity and preventing poor outcomes would benefit committed patients. Therefore, this study was an epidemiological study at a maternity transfer centre in Southeast China that aimed to identify local disease features of maternal sepsis.

Methods: This was a local epidemiological study in at a tertiary care center in Guangzhou, China, from 2015 to 2019 . A total of 74969 pregnant women experiencing childbirth were included in this study; of these women, 74 patients with maternal sepsis were diagnosed by the sepsis criterion, and 118 patients without sepsis in the same period were selected randomly as the control group to study possible reasons for postpartum sepsis. This experiment covers the whole period from first trimester to puerperium. The clinical data were collected via the hospital electronic medical record system. Singlefactor regression and multivariate logistic regression were implemented to analyze the risk factors for maternal sepsis.

Results: The incidence of maternal sepsis was $0.099 \%$, the maternal mortality ratio was $0.004 \%$ and the fetal mortality ratio was $\mathbf{0 . 0 0 7 \%}$. For clinical manifestations, septic shock was associated with a higher severity of patient illness. All of the poor outcomes (maternal or fetal death) occurred during pregnancy. Postpartum sepsis had the longest onset period, and postpartum sepsis was associated with the premature rupture of fetal membranes and preeclampsia.

Conclusions: Maternal sepsis is an important cause of both maternal and fetal mortality. Here we described an epidemiological study that evaluated the disease incidence, development and prognosis of local maternal sepsis. Furthermore, the characteristics of maternal sepsis is likely due to unknown pathological mechanisms, and patients would benefit from the identification of more effective treatments for maternal sepsis.

\section{Background}

Sepsis is defined as "a severe, potentially fatal, organic dysfunction caused by an inadequate or dysregulated host response to infection" by the latest consensus [1], and it seriously threatens global human health because of its high incidence and mortality [2]. According to ongoing epidemiological investigations, the incidence and mortality of sepsis continue to decline yearly, and the severity of sepsis is associated with the economic development of the affected population [2]. Maternal sepsis develops in women during pregnancy and puerperium, and poor outcomes include maternal or fetal mortality. In the literature, the global epidemiological descriptions of maternal sepsis are lacking, the incidences in different countries are similar $(0.1-0.3 \%)[3,4]$, and it is alarming that the incidences are consistently increasing yearly in the United Kingdom [5] and the United States of America [6]. Compared with the case fatality rate of sepsis (nearly 20\%) [7, 8], the mortality rate of maternal sepsis is extremely low. Epidemiological reports have suggested that future studies focus on a long time period (minimum 5-year time span) to define epidemiological characteristics [9], but the mortality rate was reported to have decreased in the latest study [10]. At the same time, there are few data covering the whole pregnancy and puerperium. However, complex factors that affect maternal sepsis initiation, development and prognosis, including race, climate, economic development, and medical and healthcare conditions still need further study. Our retrospective epidemiological study could benefit local and regional populations.

For the analysis of maternal sepsis in our location, this retrospective study focused on characteristic and associated factors of maternal sepsis. According to the latest definitions and classifications of sepsis, the diagnoses were sepsis and septic shock [1], as well as maternal sepsis [11]. Sepsis-induced shock is characterized by severe clinical symptoms and poor outcomes, and the clinical symptoms could be evaluated by the obstetric-modified quick sequential organ failure assessment (omSOFA) score [12] and the acute physiology and chronic health evaluation II (APACHE II) score [13]. Microbial culture and isolation could be obtained from body fluids [14], and the microbial isolates were the most concerning factor in a previous maternal sepsis study [3]. The organisms varied during different onset times, leading to different 
disease outcomes. The most serious risk factor was caused by Group A Streptococcus [6, 15]. The whole maternal period could be divided into three sections: intrapartum, antenatal and postnatal. The postnatal period is defined as the period after the fetus is delivered, and the intrapartum and antenatal periods are the periods most associated with poor outcomes affecting the fetus. Previous epidemiological research on maternal sepsis has focused on a single period in the pregnancy (i.e., the intrapartum or antenatal period) [16] or on the puerperium (i.e., the postnatal period) [17, 18]. Some demographics have also been statistically analyzed, such as age, obesity, mode of delivery and complications, which increase the incidence of maternal sepsis $[3,19]$.

In this study, we focused on maternal sepsis in a maternity transfer centre. Clinical data on the affected cases were collected and summarized to identify their characteristics, and the poor outcomes of maternal or fetal death occurred mainly during the antepartum and intrapartum periods. Postnatal cases were the most common maternal sepsis cases in our study but did not lead to poor outcomes. Statistical analysis was conducted to determine which factors increased the incidence of sepsis (Fig. 1). Collectively, we demonstrated the clinical characteristics of maternal sepsis in Southeast China, detailed the clinical features of poor outcome cases, and determined the possible reasons that could increase the incidence of postnatal sepsis.

\section{Methods}

\section{Study population}

This study was conducted at Guangdong Women's and Children's Hospital. Ethical approval was acquired from the Institutional Review Board of Guangdong Women and Children Hospital, Guangzhou, Guangdong, China. We confirmed that all research was performed in accordance with relevant guidelines/regulations, and informed consent was obtained from all participants and/or their legal guardians. There were 74969 pregnant women treated as inpatients for labor and delivery from 2015 to 2019 in the hospital. For this study, clinical data were collected during this period, including for all of the pregnant women with microbial infection-induced sepsis (or septic shock) and randomly selected control patients. Patients with acute pulmonary embolism, amniotic fluid embolism, adverse drug reactions, drug fever, viral infection, autoimmune conditions, and transfusion reactions were excluded from this study.

\section{Clinical data}

Sepsis and septic shock were diagnosed according to the criteria of the Third International Consensus Definitions for Sepsis and Septic Shock [1]. Bacterial agents were confirmed by cultures of the blood and other sites as clinically indicated, including urine culture, vaginal swabs, episiotomy wound swabs, cerebrospinal fluid, respiratory swabs and cesarean wound swabs. Onset timing was classified into antepartum, intrapartum and postpartum. Antepartum was the time from the confirmation of pregnancy to the beginning of labor defined by contractions, intrapartum was the time from the onset of labor to the delivery of the placenta, and postpartum was the 42-day period following the delivery of the placenta. The obstetric information obtained included age, infection source, infection site, gestation/stage at delivery, mode of delivery, maternal complications, maternal ICU (intensive care unit) admission time, and maternal outcome as well as neonatal data including gestational age at delivery, fetal and neonatal outcomes and mode of delivery. The APACHE II score and the obstetrically improved Sequential Organ Failure Assessment (omSOFA) score on the first day of ICU admission were recorded to evaluate the severity of illness.

The factors associated with postpartum delivery after the statistical analysis included mode of delivery, age, body mass index (BMI), primipara, in vitro fertilization (IVF), premature rupture of membrane (PROM), gestational diabetes and preeclampsia/eclampsia. PROM refers to the disruption of fetal membranes before delivery and is characterized as a painless surge of fluid that leaks out of the vagina. The diagnosis of gestational diabetes was based on the fasting $75 \mathrm{~g}$ oral glucose tolerance test during pregnancy and was diagnosed if fasting glucose was $\geq 5.8$ or 1-h glucose was $\geq 10$ $\mathrm{mmol} / \mathrm{L}$ or 2-h glucose was $\geq 11.1 \mathrm{mmol} / \mathrm{L}$. The diagnosis of preeclampsia required the confirmation of hypertension 
arising after 20 weeks of gestation on 2 or more occasions and one or more of the organ/system features related to the mother and/or fetus.

\section{Statistical analyses}

Descriptive statistical analyses were performed using means with standard deviations and medians with ranges and frequencies. Parameters were analyzed using the Fisher's exact test, chi-square test, and t test. All P values were two-sided, and $\mathrm{P}<0.05$ was considered statistically significant. The risk factors were analyzed by multivariate logistic regression. Statistical analyses were performed with SPSS version 22.0.

\section{Results}

\section{The incidence of septic shock was associated with the clinical score when sepsis occurred in pregnant women}

There were 74969 confined women included in this study from 2015 to 2019 . According to the criteria for sepsis and septic shock [1], 42 pregnant women were sepsis patients (the incidence was 5.6 per 10,000), and 32 had septic shock (4.3 per 10,000). There were no significant differences between the sepsis and septic shock groups, including age, maternal ICU admission (days), IVF and poor outcomes (Table 1). There were more cases of septic shock in the antenatal period than in the puerperium sepsis group $(p<0.05)$ (Table 1$)$. The pregnant women with septic shock had higher APACHE II and omSOFA scores than those with sepsis $(p<0.05)($ Table 1$)$.

\section{The pathogens were associated with period of onset}

In all isolates, there were 33 postnatal (44.59\% in all), 10 intrapartum (13.51\%) and 31 antenatal (41.89\%) isolates (Table 2). Regarding pathogens, two were detected in all periods of onset: Escherichia coli and Klebsiella pneumonia (Table 2). The organisms causing sepsis differed over time. Four pathogens were detected in two periods, and the others were detected in only one period. Five pathogens were detected only in the postpartum, two were detected in the intrapartum period and eight were detected in the antepartum period, as the organisms of antenatal infection were more varied than those in the postpartum and intrapartum periods (Table 2).

\section{Poor outcomes of sepsis in pregnant women were associated with infection time and organism}

The poor outcomes of pregnant women with antepartum infection-induced sepsis included maternal or fetal death. In our study, there were three antepartum cases resulting in maternal death (maternal mortality ratio was $0.004 \%$ ), which all occurred after 28 weeks, and the fetuses survived by cesarean section. The infection sites and organisms were different in these cases, and the organisms were unique in our study (Table 3). Five antepartum cases resulted in fetal death (fetal mortality ratio was $0.007 \%$ ), and infection occurred in the first and second trimesters. Three pregnant women with blood infections had unique organisms cultured in our study, and the pathogens of two pregnant women with genital tract infections all resulted in fetal surival (Table 3).

\section{Postpartum sepsis cases did not result in maternal death and were associated with pregnancy factors}

In our included postpartum sepsis cases, no maternal death occurred. Statistical analysis was conducted to interpret the correlation between postpartum sepsis occurrence and pregnancy factors. The factors that showed no association were cesarean section, age, body mass index (BMI), primipara, in vitro fertilization (IVF) and gestational diabetes. The factors that showed a significant association were premature rupture of fetal membranes (PROM) and preeclampsia/eclampsia (Table 4).

\section{Dicussion}


The incidence and mortality of maternal sepsis in different locations shared similarities but had differences. The maternal mortality ratio has continued to decrease globally in recent decades, especially in Southeast Asia [20], but data on maternal sepsis are lacking. Pregnant women who met the criteria for sepsis had a significant increase in the mortality rate compared with those without sepsis [10], and a previous study focusing on race and ethnicity and cases of maternal sepsis indicated that disparities existed [21]. In this study, we documented the incidence $(0.099 \%)$ and mortality ratio $(0.004 \%)$. The incidence was consistent with that of developed countries but higher than that of West China, and the mortality was the highest $[5,6,10,22]$. The differences in the clinical manifestations of sepsis in the population could be due to many reasons. In our previous study, we indicated that genetics was an important factor affecting the incidence, development and prognosis of sepsis [23], and genetic differences could be the primary reason for the difference in maternal sepsis by race. China has the largest population in the world, but epidemiological studies covering the entire scope of maternal sepsis are lacking. Maternal sepsis differences in various places exist due to differences in economic development, climate, people's habits and customs. Over seventy thousand clinical data points were collected over five years in our study, but this study limited to a Transfer Center for pregnant women in Southeast China. More studies are needed in order to organize a larger scope study.

The gestation time of maternal sepsis was associated with sepsis severity and the pathogenic microorganisms that were isolated. The maternal period was divided into the antepartum, intrapartum and postpartum periods, as bodily changes in pregnant women may mask the signs of sepsis [24]. Rapid diagnosis and management are very important in addressing maternal sepsis [25]. Antepartum was defined as the initial part of pregnancy before birth and was the longest period of the three; furthermore, infections isolated in this period showed a diversity of affected sites and in the type of microorganisms isolated [26]. In our study, patients with antepartum sepsis had a higher risk of septic shock, and evidence showed that all of the maternal deaths and most of the fetal deaths occurred in this period. Puerperium includes the intrapartum and postpartum periods, and this period is shorter than the antepartum period. Sepsis in this period could be referred to as delivery-associated sepsis, and the risk of fatality to mothers with sepsis was highest in this period [10]. In our study, the poor outcome of this period was the high loss of fetuses. Gram-negative bacteria are the most common isolates during the whole maternal period, and Escherichia coli is a frequently isolated pathogenic microorganism in maternal sepsis [3, 4]. The most common gram-positive bacteria isolated was Streptococcus[27], and Group A Streptococcusis regarded as the top risk factor of maternal mortality [15]. In our study, the top three common isolates were Escherichia coli, Klebsiella pneumoniae and Enterococcus faecalis. There were two Streptococcus isolates and one fungal isolate in the three maternal mortality cases. Fetal loss was a more common issue in maternal sepsis than maternal mortality, and microorganism isolation was diverse.

Postpartum sepsis was the most common scenario in our study. There were some reasons that maternal sepsis was high in this period, and these included PROM [17], diabetes [28] and the mode of delivery [3]. The consistent results of this period suggest a higher risk factor, such as diabetes, being a significant risk factor associated with postpartum sepsis [17, 28], but the opposite also existed, such as cesarean delivery [3,17], a possible reason for the different populations. In the current study, two factors were associated with postpartum sepsis: PROM and preeclampsia/eclampsia. PROM is one of the common reasons for preterm birth, which can be caused by infection or as a consequence of infection [29]. PROMassociated infection could be the reason for the high sepsis incidence. Preeclampsia/eclampsia and maternal sepsis were both leading causes of near-miss mothers [30], and additional studies are needed to interpret the causal relationship between them and develop management protocols to protect mothers against these conditions.

Pregnancy is a miraculous experience, and it is the process of birthing a new life; additionally, there could be a rejuvenating effect on the mother [31]. Evidence to confirm this includes the fact that fetal cells transfer to the mother [32] in humans, and fetal cells participate in maternal wound healing [33] in animal studies. Maternal sepsis has a lower mortality rate than other causes of sepsis, even in the matched controls [34]; however, due to the characteristics of affected individuals, the precise mechanism is unknown. Materials from pregnancy and childbirth provide medical means to treat sepsis. In a previous study, we demonstrated that mesenchymal stem cells (MSCs) derived from the amniotic fluid of the second 
trimester (AF-MSCs) and Wharton's jelly of the umbilical cord (UC-MSCs) showed a curative effect in an experimental sepsis animal model [35]. In maternal sepsis, the hypothesis that the internal MSCs associated with the pregnancy and childbirth process relieve the acute inflammatory response needs more experimental evidence. MSC cytotherapy is widely accepted as a potential therapeutic strategy to treat acute injury inflammatory diseases, including COVID-19 [36]. Although AFMSCs have been indicated to improve the survival of neonatal sepsis in a rat model [37], evidence that MSCs from different sources are effective in relieving maternal sepsis is lacking, and this would be necessary to further study before the clinical usage of MSC cryotherapy to treat maternal sepsis.

\section{Conclusions}

In summary, we demonstrated the clinical characteristics of maternal sepsis in Guangzhou and isolated the organisms at different infection times. Furthermore, some useful data were identified, including poor outcomes during pregnancy and the associated reasons for postpartum sepsis. This work would help affected patients by demonstrating the pathological features of the local maternal sepsis process and identifying effective treatment options.

\section{Declarations}

Acknowledgements Not applicable.

Code availability Not applicable.

\section{Author contribution}

DW and ZX designed the study. ZX performed the experiments and statistical analyses. DW and ZX wrote the paper. Luo YP, Lin RF and Zhang WN analyzed the data. All authors read and approved the final manuscript.

\section{Funding}

This study was supported by a Guangzhou Education Bureau-funded project (202032868) , Guangzhou Science and technology project (202102010105) and the Traditional Chinese Medicine Bureau of Guangdong Province (No:20211045). The funding sources and sponsors did not participate in the design of the study; the collection, analysis, and interpretation of data; or in writing the manuscript.

\section{Ethical approval and consent to participate}

This study was approved by the Institutional Review Board of Women's and Children's Hospital. Written informed consent of participant (or patient family members) was provided.

\section{Consent to participate}

Oral and written informed consent was obtained from the participants.

\section{Consent for publication}

The authors have seen the final version of the manuscript and approved submission for publication.

\section{Data availability statement}

The datasets generated during and/or analysed during the current study are not publicly available due to individual privacy. The clinical data of all patients were inputted into a software (HIS, hospital information management system, Feibo Technology Co.Ltd,Wuhan,China) by the medical staffs. All the data are only available to the internal without web link for the external, but are available from the corresponding author on reasonable request. 
The authors have no conflicts of interest to declare.

\section{References}

1. Singer M, Deutschman CS, Seymour CW, Shankar-Hari M, Annane D, Bauer M, Bellomo R, Bernard GR, Chiche JD, Coopersmith CM et al: The Third International Consensus Definitions for Sepsis and Septic Shock (Sepsis-3). Jama 2016, 315(8):801-810.

2. Rudd KE, Johnson SC, Agesa KM, Shackelford KA, Tsoi D, Kievlan DR, Colombara DV, Ikuta KS, Kissoon N, Finfer S et al: Global, regional, and national sepsis incidence and mortality, 1990-2017: analysis for the Global Burden of Disease Study. Lancet 2020, 395(10219):200-211.

3. Knowles SJ, O'Sullivan NP, Meenan AM, Hanniffy R, Robson M: Maternal sepsis incidence, aetiology and outcome for mother and fetus: a prospective study. BJOG : an international journal of obstetrics and gynaecology 2015, 122(5):663-671.

4. Surgers L, Valin N, Carbonne B, Bingen E, Lalande V, Pacanowski J, Meyohas MC, Girard PM, Meynard JL: Evolving microbiological epidemiology and high fetal mortality in 135 cases of bacteremia during pregnancy and postpartum. European journal of clinical microbiology \& infectious diseases : official publication of the European Society of Clinical Microbiology 2013, 32(1):107-113.

5. Cantwell R, Clutton-Brock T, Cooper G, Dawson A, Drife J, Garrod D, Harper A, Hulbert D, Lucas S, McClure J et al: Saving Mothers' Lives: Reviewing maternal deaths to make motherhood safer: 2006-2008. The Eighth Report of the Confidential Enquiries into Maternal Deaths in the United Kingdom. BJOG : an international journal of obstetrics and gynaecology 2011, 118 Suppl 1:1-203.

6. Bauer ME, Bateman BT, Bauer ST, Shanks AM, Mhyre JM: Maternal sepsis mortality and morbidity during hospitalization for delivery: temporal trends and independent associations for severe sepsis. Anesthesia and analgesia 2013, 117(4):944-950.

7. Gaieski DF, Edwards JM, Kallan MJ, Carr BG: Benchmarking the incidence and mortality of severe sepsis in the United States. Critical care medicine 2013, 41(5):1167-1174.

8. Kaukonen KM, Bailey M, Suzuki S, Pilcher D, Bellomo R: Mortality related to severe sepsis and septic shock among critically ill patients in Australia and New Zealand, 2000-2012. Jama 2014, 311(13):1308-1316.

9. Bouvier-Colle MH, Mohangoo AD, Gissler M, Novak-Antolic Z, Vutuc C, Szamotulska K, Zeitlin J, Euro-Peristat Scientific $\mathrm{C}$ : What about the mothers? An analysis of maternal mortality and morbidity in perinatal health surveillance systems in Europe. BJOG : an international journal of obstetrics and gynaecology 2012, 119(7):880-889; discussion 890.

10. Kendle AM, Salemi JL, Tanner JP, Louis JM: Delivery-associated sepsis: trends in prevalence and mortality. American journal of obstetrics and gynecology 2019, 220(4):391 e391-391 e316.

11. Greer O, Shah NM, Sriskandan S, Johnson MR: Sepsis: Precision-Based Medicine for Pregnancy and the Puerperium. International journal of molecular sciences 2019, 20(21).

12. Bowyer L, Robinson HL, Barrett H, Crozier TM, Giles M, Idel I, Lowe S, Lust K, Marnoch CA, Morton MR et al: SOMANZ guidelines for the investigation and management sepsis in pregnancy. The Australian \& New Zealand journal of obstetrics \& gynaecology 2017, 57(5):540-551.

13. Zabolotskikh IB, Musaeva TS, Denisova EA: [Validity of APACHE II, APACHE III, SAPS 2, SAPS 3 and SOFA scales in obstetric patients with sepsis]. Anesteziologiia i reanimatologiia 2012(6):55-57.

14. Kankuri E, Kurki T, Carlson P, Hiilesmaa V: Incidence, treatment and outcome of peripartum sepsis. Acta obstetricia et gynecologica Scandinavica 2003, 82(8):730-735. 
15. Phillips C, Walsh E: Group A Streptococcal Infection During Pregnancy and the Postpartum Period. Nursing for women's health 2020, 24(1):13-23.

16. Barinov SV, Tirskaya YI, Kadsyna TV, Lazareva OV, Medyannikova IV, Tshulovski YI: Pregnancy and delivery in women with a high risk of infection in pregnancy. The journal of maternal-fetal \& neonatal medicine : the official journal of the European Association of Perinatal Medicine, the Federation of Asia and Oceania Perinatal Societies, the International Society of Perinatal Obstet 2020:1-6.

17. Bakhtawar S, Sheikh S, Qureshi R, Hoodbhoy Z, Payne B, Azam I, von Dadelszen P, Magee L: Risk factors for postpartum sepsis: a nested case-control study. BMC pregnancy and childbirth 2020, 20(1):297.

18. Woodd SL, Montoya A, Barreix M, Pi L, Calvert C, Rehman AM, Chou D, Campbell OMR: Incidence of maternal peripartum infection: A systematic review and meta-analysis. PLoS medicine 2019, 16(12):e1002984.

19. Sriskandan S: Severe peripartum sepsis. The journal of the Royal College of Physicians of Edinburgh 2011, 41(4):339346.

20. Kassebaum NJ, Bertozzi-Villa A, Coggeshall MS, Shackelford KA, Steiner C, Heuton KR, Gonzalez-Medina D, Barber R, Huynh C, Dicker D et al: Global, regional, and national levels and causes of maternal mortality during 1990-2013: a systematic analysis for the Global Burden of Disease Study 2013. Lancet 2014, 384(9947):980-1004.

21. Grobman WA, Bailit JL, Rice MM, Wapner RJ, Reddy UM, Varner MW, Thorp JM, Jr., Leveno KJ, Caritis SN, lams JD et al: Racial and ethnic disparities in maternal morbidity and obstetric care. Obstetrics and gynecology 2015, 125(6):1460-1467.

22. Duan $\mathrm{R}$, Xu X, Wang $\mathrm{X}, \mathrm{Yu} \mathrm{H}$ : Perinatal outcome in women with bacterial sepsis: A cross-sectional study from West China. Medicine 2019, 98(44):e17751.

23. Wang D, Zhong X, Huang D, Chen R, Bai G, Li Q, Yu B, Fan Y, Sun X: Functional polymorphisms of interferon-gamma affect pneumonia-induced sepsis. PloS one 2014, 9(1):e87049.

24. Guinn DA, Abel DE, Tomlinson MW: Early goal directed therapy for sepsis during pregnancy. Obstetrics and gynecology clinics of North America 2007, 34(3):459-479, xi.

25. Galvao A, Braga AC, Goncalves DR, Guimaraes JM, Braga J: Sepsis during pregnancy or the postpartum period. Journal of obstetrics and gynaecology : the journal of the Institute of Obstetrics and Gynaecology 2016, 36(6):735-743.

26. Adorno M: Sepsis in the Obstetric Client. Critical care nursing clinics of North America 2018, 30(3):415-422.

27. Seale AC, Bianchi-Jassir F, Russell NJ, Kohli-Lynch M, Tann CJ, Hall J, Madrid L, Blencowe H, Cousens S, Baker CJ et al: Estimates of the Burden of Group B Streptococcal Disease Worldwide for Pregnant Women, Stillbirths, and Children. Clinical infectious diseases : an official publication of the Infectious Diseases Society of America 2017, 65(suppl_2):S200-S219.

28. Acosta CD, Knight M, Lee HC, Kurinczuk JJ, Gould JB, Lyndon A: The continuum of maternal sepsis severity: incidence and risk factors in a population-based cohort study. PloS one 2013, 8(7):e67175.

29. Kenyon S, Boulvain M, Neilson JP: Antibiotics for preterm rupture of membranes. The Cochrane database of systematic reviews 2013(12):CD001058.

30. Oppong SA, Bakari A, Bell AJ, Bockarie Y, Adu JA, Turpin CA, Obed SA, Adanu RM, Moyer CA: Incidence, causes and correlates of maternal near-miss morbidity: a multi-centre cross-sectional study. BJOG : an international journal of obstetrics and gynaecology 2019, 126(6):755-762.

31. Falick Michaeli T, Bergman Y, Gielchinsky Y: Rejuvenating effect of pregnancy on the mother. Fertility and sterility 2015, 103(5):1125-1128.

32. Mahmood U, O'Donoghue K: Microchimeric fetal cells play a role in maternal wound healing after pregnancy. Chimerism 2014, 5(2):40-52.

33. Nassar D, Droitcourt C, Mathieu-d'Argent E, Kim MJ, Khosrotehrani K, Aractingi S: Fetal progenitor cells naturally transferred through pregnancy participate in inflammation and angiogenesis during wound healing. FASEB journal : 
official publication of the Federation of American Societies for Experimental Biology 2012, 26(1):149-157.

34. Kidson KM, Henderson WR, Hutcheon JA: Case Fatality and Adverse Outcomes Are Reduced in Pregnant Women With Severe Sepsis or Septic Shock Compared With Age-Matched Comorbid-Matched Nonpregnant Women. Critical care medicine 2018, 46(11):1775-1782.

35. Chen R, Xie Y, Zhong X, Chen F, Gong Y, Wang N, Wang D: MSCs derived from amniotic fluid and umbilical cord require different administration schemes and exert different curative effects on different tissues in rats with CLP-induced sepsis. Stem cell research \& therapy 2021, 12(1):164.

36. Coelho A, Alvites RD, Branquinho MV, Guerreiro SG, Mauricio AC: Mesenchymal Stem Cells (MSCs) as a Potential Therapeutic Strategy in COVID-19 Patients: Literature Research. Frontiers in cell and developmental biology 2020, 8:602647.

37. Sato Y, Ochiai D, Abe Y, Masuda H, Fukutake M, Ikenoue S, Kasuga Y, Shimoda M, Kanai Y, Tanaka M: Prophylactic therapy with human amniotic fluid stem cells improved survival in a rat model of lipopolysaccharide-induced neonatal sepsis through immunomodulation via aggregates with peritoneal macrophages. Stem cell research \& therapy 2020, 11(1):300.

\section{Tables}

Table 1. Clinical information of maternal sepsis

\begin{tabular}{|c|c|c|c|c|c|c|c|}
\hline & & $\begin{array}{l}\text { Sepsis } \\
(n=42)\end{array}$ & $\begin{array}{l}\text { Septic shock } \\
(n=32)\end{array}$ & OR & $95 \% \mathrm{Cl}$ & $\begin{array}{l}P \\
\text { value }\end{array}$ & Total $(n=74)$ \\
\hline \multirow[t]{2}{*}{ Age (years) } & Mean $\pm S D$ & $30.76 \pm 5.63$ & $30.41 \pm 6.549$ & 0.99 & $\begin{array}{l}0.916- \\
1.07\end{array}$ & 0.803 & $30.61 \pm 6.004$ \\
\hline & Range & $18-44$ & $18-49$ & & & & $18-49$ \\
\hline \multirow[t]{2}{*}{$\begin{array}{l}\text { Maternal ICU admission } \\
\text { (days) }\end{array}$} & Mean $\pm S D$ & $5.48 \pm 2.391$ & $6.22 \pm 6.656$ & 1.035 & $\begin{array}{l}0.932- \\
1.15\end{array}$ & 0.516 & $5.8 \pm 4.708$ \\
\hline & Range & $2-11$ & $1-40$ & & & & $1-40$ \\
\hline IVF & $n(\%)$ & 5 & 3 & 1.306 & $\begin{array}{l}0.288- \\
5.923\end{array}$ & 0.518 & 8 \\
\hline \multirow[t]{2}{*}{ APACHE II Score } & Mean $\pm S D$ & $10.5 \pm 6.05$ & $14.22 \pm 5.999$ & 1.111 & $\begin{array}{l}1.02- \\
1.211\end{array}$ & 0.016 & $12.11 \pm 6.267$ \\
\hline & Range & $1-35$ & $2-27$ & & & & $1-35$ \\
\hline \multirow[t]{2}{*}{ omSOFA Score } & Mean $\pm S D$ & $1.48 \pm 1.851$ & $2.44 \pm 1.848$ & 1.339 & $\begin{array}{l}1.016- \\
1.766\end{array}$ & 0.038 & $1.89 \pm 1.899$ \\
\hline & Range & $0-10$ & $0-6$ & & & & $0-10$ \\
\hline \multicolumn{8}{|l|}{ Period of onset } \\
\hline Antenatal & $n(\%)$ & $12 \rrbracket 28.6 \rrbracket$ & $19 \otimes 59.4 \rrbracket$ & 9.135 & $\begin{array}{l}2.212- \\
8.207\end{array}$ & 0.004 & $31 \rrbracket 41.9 \rrbracket$ \\
\hline puerperium & $\mathrm{n}(\%)$ & $30 \otimes 71.4 \rrbracket$ & $13 \rrbracket 40.6 \rrbracket$ & & & & \\
\hline \multicolumn{8}{|l|}{ Poor outcome } \\
\hline Fetal death & $\mathrm{n}(\%)$ & $3 \otimes 7.1 \rrbracket$ & 6ه18.8\ & 3 & $\begin{array}{l}0.688- \\
13.075\end{array}$ & 0.125 & $9 \rrbracket 12.2 \rrbracket$ \\
\hline Maternal death & $n(\%)$ & $1 \otimes 2.4 \rrbracket$ & $2 \varangle 6.3 \rrbracket$ & 2.733 & $\begin{array}{l}0.237- \\
31.555\end{array}$ & 0.398 & $3 \varangle 4.1 \rrbracket$ \\
\hline
\end{tabular}


ICU: intensive care unit; IVF: in vitro fertilization; omSOFA: obstetric-modified quick sequential organ failure assessment; APACHE II: acute physiology and chronic health evaluation II

Table 2. Pathogens of maternal sepsis

\begin{tabular}{|c|c|c|c|c|}
\hline Organism & Postpartum(n) & Intrapartum(n) & Antepartum (n) & All isolates(n) \\
\hline Escherichia coil & 21 & 3 & 14 & 37 \\
\hline Klebsiella pneumonia & 3 & 2 & 2 & 7 \\
\hline Hemolytic Staphylococcus & 1 & 0 & 1 & 2 \\
\hline Streptococcus gallolyticus & 1 & 0 & 0 & 2 \\
\hline Enterococcus faecalis & 5 & 0 & 0 & 5 \\
\hline Enterococcus avium & 1 & 0 & 0 & 1 \\
\hline Prevotella oralis & 1 & 0 & 0 & 1 \\
\hline Listeria & 0 & 1 & 1 & 2 \\
\hline Mycoplasma pneumoniae & 0 & 1 & 2 & 3 \\
\hline Streptococcus agalactiae & 0 & 1 & 1 & 2 \\
\hline Gardnerella vaginalis & 0 & 1 & 0 & 1 \\
\hline Stenotrophomonas maltophilia & 0 & 1 & 0 & 1 \\
\hline Morganella morganii & 0 & 0 & 1 & 1 \\
\hline Enterobacter cloacae & 0 & 0 & 2 & 2 \\
\hline Pseudomonas putida & 0 & 0 & 1 & 1 \\
\hline Brucella Maltese & 0 & 0 & 1 & 1 \\
\hline Streptococcus pneumoniae & 0 & 0 & 1 & 1 \\
\hline Salmonella typhi & 0 & 0 & 1 & 1 \\
\hline Pseudomonas aeruginosa & 0 & 0 & 1 & 1 \\
\hline Aspergillus & 0 & 0 & 1 & 1 \\
\hline Streptococcus haemolyticus & 0 & 0 & 1 & 1 \\
\hline Total & 33 & 10 & 31 & 74 \\
\hline
\end{tabular}


Table 3. Poor outcome of maternal sepsis

\begin{tabular}{|c|c|c|c|c|c|c|c|}
\hline $\begin{array}{l}\text { Maternal } \\
\text { outcome/Fetal } \\
\text { outcome }\end{array}$ & $\begin{array}{l}\text { Infecting } \\
\text { time }\end{array}$ & $\begin{array}{l}\text { Mode of } \\
\text { delivery }\end{array}$ & $\begin{array}{l}\text { Delivery } \\
\text { weeks }\end{array}$ & $\begin{array}{l}\text { Infecting } \\
\text { weeks }\end{array}$ & $\begin{array}{l}\text { Infection } \\
\text { site }\end{array}$ & $\begin{array}{l}\text { Infecting } \\
\text { bacteria }\end{array}$ & $\begin{array}{l}\text { singleton/multiple } \\
\text { pregnancy }\end{array}$ \\
\hline \multirow[t]{3}{*}{ Died/Survival } & \multirow[t]{3}{*}{ Antepartum } & CS & $36+$ & $36+$ & Blood & $\begin{array}{l}\text { Streptococcus } \\
\text { haemolyticus }\end{array}$ & singleton \\
\hline & & CS & $34+$ & $30+$ & $\begin{array}{l}\text { Intracranial } \\
\text { infection }\end{array}$ & $\begin{array}{l}\text { Streptococcus } \\
\text { pneumoniae }\end{array}$ & singleton \\
\hline & & CS & $32+$ & $32+$ & $\begin{array}{l}\text { respiratory } \\
\text { tract }\end{array}$ & Aspergillus & singleton \\
\hline \multirow[t]{9}{*}{ Survival/Died } & \multirow[t]{5}{*}{ Antepartum } & Abortion & $8+$ & $8+$ & $\begin{array}{l}\text { Genital } \\
\text { tract }\end{array}$ & $\begin{array}{l}\text { Escherichia } \\
\text { coil }\end{array}$ & twin \\
\hline & & Abortion & $24+$ & $24+$ & Blood & $\begin{array}{l}\text { Pseudomonas } \\
\text { putida }\end{array}$ & singleton \\
\hline & & CS & $22+$ & $21+$ & Blood & $\begin{array}{l}\text { Morganella } \\
\text { morganii }\end{array}$ & singleton \\
\hline & & CS & $21+$ & $21+$ & $\begin{array}{l}\text { Genital } \\
\text { tract }\end{array}$ & $\begin{array}{l}\text { Streptococcus } \\
\text { agalactiae }\end{array}$ & singleton \\
\hline & & Abortion & $14+$ & $12+$ & Blood & $\begin{array}{l}\text { Brucella } \\
\text { maltese }\end{array}$ & singleton \\
\hline & \multirow[t]{2}{*}{ Intrapartum } & $\mathrm{CS}$ & $25+$ & $25+$ & Blood & $\begin{array}{l}\text { Streptococcus } \\
\text { gallolyticus }\end{array}$ & singleton \\
\hline & & Abortion & $35+$ & $36+$ & Blood & $\begin{array}{l}\text { Enterococcus } \\
\text { faecalis }\end{array}$ & singleton \\
\hline & \multirow[t]{2}{*}{ Postpartum } & Abortion & $23+$ & $23+$ & Blood & $\begin{array}{l}\text { Streptococcus } \\
\text { agalactiae }\end{array}$ & singleton \\
\hline & & Abortion & $13+$ & $13+$ & Blood & $\begin{array}{l}\text { Escherichia } \\
\text { coil }\end{array}$ & singleton \\
\hline
\end{tabular}

CS: Caesarean section

Table 4. Correlation of pregnancy factors and Postpartum sepsis

\begin{tabular}{|c|c|c|c|c|}
\hline Covariate & $\begin{array}{l}\text { Postpartum sepsis } \\
\bigotimes n=33 \rrbracket\end{array}$ & $\begin{array}{l}\text { Control population } \\
\bigotimes n=118 \rrbracket\end{array}$ & $\begin{array}{l}\text { Adjusted odds ratio (95 } \\
\mathrm{Cl})\end{array}$ & $\begin{array}{l}\mathrm{P} \\
\text { value }\end{array}$ \\
\hline Caesarean section & $25 \bigotimes 75.8 \rrbracket$ & $46 \rrbracket 39.0 \rrbracket$ & 1.747(0.684-7.041ه & 0.186 \\
\hline Age $\geq 34$ years $^{c}$ & $10 \rrbracket 30.3 \rrbracket$ & $24 \llbracket 20.3 \rrbracket$ & $1.094(-0.070-0.245 \rrbracket$ & 0.276 \\
\hline $\mathrm{BMI} \geq 30 \mathrm{~kg} / \mathrm{m}^{2 \mathrm{~d}}$ & $4 \otimes 12.1 \rrbracket$ & $12 \rrbracket 10.2 \rrbracket$ & $0.320(-0.182-0.252)$ & 0.749 \\
\hline Primipara & $22 \bowtie 66.7 \rrbracket$ & $34 \rrbracket 28.8 \rrbracket$ & $2.107(0.688-6.449)$ & 0.192 \\
\hline IVFe & $3 \otimes 9.1 \rrbracket$ & $10 \llbracket 8.5 \rrbracket$ & $0.111(-0.225-0.252)$ & 0.912 \\
\hline PROM $^{f}$ & $11 \bowtie 33.3 \rrbracket$ & $8 \rrbracket 6.8 \rrbracket$ & $5.498(1.737-17.407)$ & 0.004 \\
\hline Gestational diabetes & $9 \llbracket 27.3 \rrbracket$ & $18 \rrbracket 15.3 \rrbracket$ & $1.596(-0.033-0.313)$ & 0.113 \\
\hline $\begin{array}{l}\text { Pre- } \\
\text { eclampsia/eclampsia }\end{array}$ & $2 \llbracket 6.1 \rrbracket$ & $5 \rrbracket 4.2 \rrbracket$ & $3.326(1.099-10.072)$ & 0.033 \\
\hline
\end{tabular}


Figures

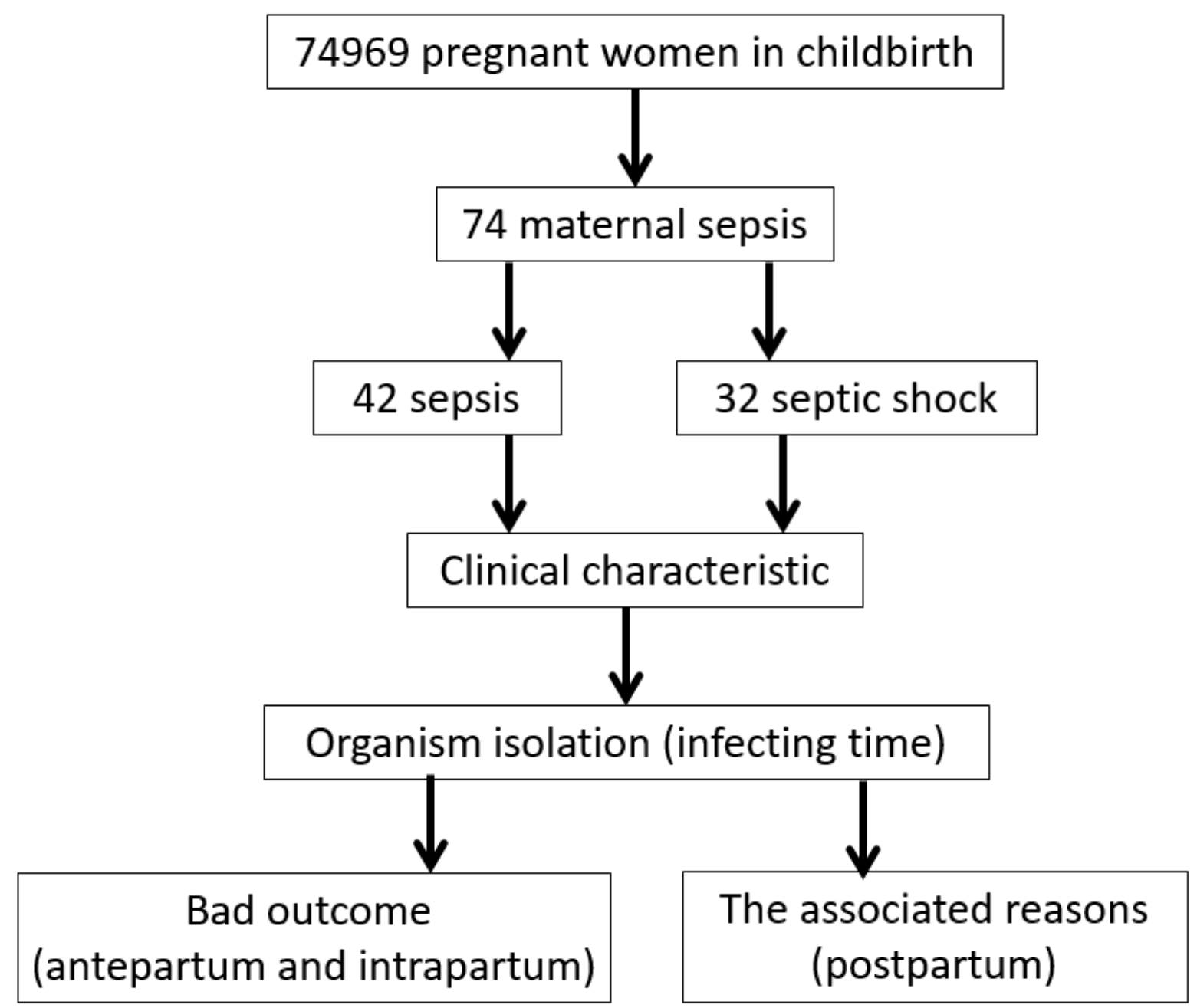

Figure 1

chematic representation of maternal sepsis 